\title{
ENKELE MINDER BEKENDE ASPECTEN VAN DE PERSONEEL-VERZEKERING
}

\author{
door Lod. S. Beuth
}

De hoge productiecijfers van de Levensverzekeringmaatschappijen in en na den oorlog vinden voor een groot gedeelte hun oorzaak in de vele verzekeringen die ten behoeve van werknemers in deze jaren tot stand kwamen. De aanleiding daartoe was van velerlei aard. Niet de geringste waren de fiscale bepalingen, die het toestonden (en toestaan) de z.g. backservice, voor zover daarop rechten aan de werknemer zijn toegekend, als schuld op te voeren. De beperking van de fiscale winst, die daarvan het gevolg was, hield, bij de toen vigerende progressieve vennootschapsen inkomstenbelasting in, dat een zéér belangrijk gedeelte van de lasten, die aan pensioentoekenning verbonden zijn, als het ware door de fiscus werden gedragen. Bovendien werkte de ruime liquiditeit in de oorlogsjaren de storting van de backservice-premie, vaak via herverzekering bij een levensverzekeringmaatschappij, krachtig in de hand. Dat men daarmede later bovendien aan de vermogensaanwasbelasting ontkwam, was een geenszins onplezierige consequentie, die echter op het ogenblik dat men de voorziening trof, niet in de overwegingen was betrokken. Belangrijke bedragen, die anders uit hoofde der fiscale heffingen voor bedrijfsdoeleinden verloren zouden zijn gegaan, bleven thans voor verlichting van toekomstige lasten (die anders als morele verplichting later tóch hun rekening zouden komen aanbieden) behouden.

$\mathrm{Na}$ de oorlog waren de investeringsbehoeften voor vernieuwing en uitbreiding, ondanks de in het algemeen ruime winsten zó groot, dat de liquiditeit in het gedrang kwam. Door het opvoeren van de backserviceschuld op de fiscale balans enerzijds en jaarpremiebetaling anderzijds, ontstond ook bij herverzekering een investeringsruimte, die weliswaar telkenjare kleiner werd door afboeking van de in de jaarpremie verwerkte ,uitgesmeerde" backservice-inhaal-premie, maar die dan toch bij de ogenblikkelijke financieringsnoden van de onderneming een begeerd soulaas bood. Daarnaast leidde de loonstop enerzijds en de noodzaak van arbeidsrust en bedrijfsvrede anderzijds tot het tot standkomen van pensioenregelingen via de C.A.O., die op hun beurt weer de stoot gaven tot voorzieningen voor hen, die niet onder de C.A.O. vielen. Door deze gang van zaken drong in ruime kring de wenselijkheid door van pensioenvoorzieningen als onderdeel van de sociale plicht van den werkgever.

De terugkeer tot ,normaler" omstandigheden heeft zich overigens nog niet afgespiegeld in afneming van de productie der levensverzekeringmaatschappijen, in het bizonder wat betreft de herverzekering van pensioenaanspraken. De op stapel staande wettelijke regeling inzake uitbreiding van taak en bevoegdheid der Verzekeringskamer (reeds aangekondigd in de Troonrede van September 1948), die haar toezicht zal gaan uitstrekken over de z.g. ondernemingspensioenfondsen, waarvan er thans nog vele ,eigenbeheer" voeren, zal ook voor de naaste toekomst deze productiecijfers wel gunstig blijven beïnvloeden.

Het is echter interessant ons rekenschap te geven van de motieven, die onder de huidige omstandigheden tot het tot stand komen van pensioenregelingen kunnen leiden, want er zijn zeker ook factoren aan te wijzen, die juist thans deze tot-stand-koming afremmen, zoals een verwachting van het teruglopen van winstmogelijkheden en de afwachtende

m a b blz. 284 
houding die men meent te moeten aannemen in verband met de nieuwe structuur der sociale wetgeving, die o.a. ook tot herziening van het z.g. bodempensioen zal leiden. Het spreekt vanzelf, dat men onder alle omstandigheden matiging en voorzichtigheid moet betrachten bij het toekennen en het formuleren van rechten, doch het zou allerminst juist zijn, de totstandkoming van een als wenselijk gevoelde maatregel op te schorten op grond van een in de toekomst te fixeren bodempensioen. De geprojecteerde voorzieningen zijn immers van geringen omvang en dekken zelfs niet het minimum levensonderhoud. De arbeider zal dus voor oudedags- en gezinsverzorging aangewezen blijven op voorzieningen boven het van Staatswege te stellen bodempensioen. De werkgever, die voor deze aanvulling maatregelen treft, zal later, wanneer in zijn bedrijfsgroep deelname aan een bedrijfspensioenfonds verplicht zou worden gesteld, van deze laatste verplichting ontheffing kunnen verkrijgen, zodat er geen sprake van is, dat men, nu (desnoods minimum-) maatregelen treffende, te zijner tijd voor „dubbele lasten” wordt geplaatst. De redenering, dat de hoger bezoldigden wel voor zich zelf kunnen zorgen, gaat in de praktijk niet op. Ook deze categorie blijft aangewezen op regelingen, die binnen de onderneming voor hen worden getroffen. Een procuratiehouder b.v. komt gemeenlijk pas op lateren leeftijd aan een inkomen van enigen omvang. Zijn gezinslasten, ook in verband met de opvoeding van zijn kinderen, zijn echter zóveel hoger dan die van een arbeider (wiens kinderen vanaf hun $16 \mathrm{e}$ jaar bovendien het gezinsinkomen versterken), dat het oversparen van bedragen, die tot het vormen van een voldoende oudedagsreserve leiden, uitgesloten is.

In het algemeen zijn de vroegere impulsen tot het invoeren van pensioenregelingen ook thans nog werkzaam en is de kracht van het sociale argument zelfs normatief versterkt. Ook is men gaan inzien, dat het belang van een spoedig tot stand te brengen regeling binnen het kader der onderneming althans voor de jongere personeelgroepen ligt in het opvangen en voorkomen van financieringsmoeilijkheden t.a.v. de backservice: die bij elk jaar uitstel groter problemen stelt.

Naast deze aspecten echter zijn er nog andere en wel van geheel anderen aard, die het tijdig tot stand brengen van pensioenvoorzieningen in de hand werken en die in het bizonder voor eigenaren van ondernemingen van kleineren omvang van belang zullen blijken. Hier mogen een paar practijkgevallen hun bijdragen tot verruiming van inzicht leveren. Deze gevallen spreken zozeer voor zich zelf, dat uitgebreid commentaar overbodig is.

Geval $A$. Iemand heeft practisch zijn gehele vermogen geïnvesteerd in zijn onderneming. Hij heeft drie kinderen, een zoon, die hem straks als directeur zal opvolgen, een tweede zoon, die kunstenaar is alsmede een dochter, wier echtgenoot een klein inkomen geniet. Hem is er veel aan gelegen, dat ook in de toekomst de onderneming baten zal blijven afwerpen en mede op grond dezer overwegingen werd besloten tot het toekennen van pensioenrechten ten behoeve van het personeel der onderneming. Enerzijds leidt dit tot vermindering der na zijn overlijden te betalen successierechten (er wordt uit de winst minder toegevoegd aan de interne reserves, waardoor de waarde der aandelen wordt gedrukt) en anderzijds - en hierom ging het i.c. - worden de toekomstige verplichtingen zo laag mogelijk gehouden, terwijl bovendien zekerheid wordt verkregen voor de oudgedienden, die niet meer bloot staan aan een moge- 
lijke intrekking van hun pensioen bij een latere slechte gang van zaken.

Geval B. Een vader heeft drie kinderen, twee dochters en een zoon. De zoon is reeds firmant in de firma van zijn vader en de bedoeling is, dat aan deze zoon - zoveel als een eerlijke verdeling van de boedel zal toelaten - de vermogensdelen belegd in de firma bij de boedelscheiding zullen worden toebedeeld. Zou de backservice (pensioenverplichtingen waren op het ogenblik van het overlijden nog niet verleend) daarbij buiten beschouwing blijven, dan zou de uit dit "verzuim" voortvloeiende verplichting t.z.t. geheel voor rekening van de zoon vallen, die bovendien benadeeld zou zijn, omdat de andere erfgenamen een boedelgedeelte ontvangen waarin met deze schuld geen rekening zou zijn gehouden.

Er bestaat een goed nederlands gezegde dat luidt: „wie zijn schulden betaalt, verarmt niet". Er bestaat eveneens een goed koopmansgebruik dat inhoudt, dat men zijn onderneming sterk maakt tegen mogelijk toekomstige onvoorziene tegenslag door reserves op te bouwen. Nu kan men het voldoen aan de morele plicht tot onderstand aan zijn werknemers moeilijk rangschikken onder het begrip „onvoorziene tegenslag”. Hoeveel te meer klemt het dan, wanneer de winstmogelijkheid en de bedrijfsfinanciering het toelaten, tijdig maatregelen in deze te treffen. Wie dit doet, dient niet alleen de belangen van onderneming en personeel, doch mede die van zich zelf en van zijne erfgenamen. 